\title{
Analysis of School Climate Factors as Predictors of Academic Achievement in Junior High Schools: A Literature Review
}

\author{
Marani Cahya Ningtias ${ }^{1}$, Suyanto $^{2}$, Amika Wardana $^{3}$, Deri Indrahadi ${ }^{4}$ \\ \{maranicahya.2019@student.uny.ac.id ${ }^{1}$, suyan@gmail.com²,a.wardana@uny.ac.id ${ }^{3}$, \\ dindrahadi@gmail.com $\left.{ }^{4}\right\}$ \\ Universitas Negeri Yogyakarta
}

\begin{abstract}
The idea that school climate is an essential construct in supporting academic achievement can be a benchmark in assessing the performance of the world education system. However, Studies on school climate indicators are well documented in the international literature, but Indonesian research on this subject is still minimal. This article aims to analyze the literature on school climate indicators that can predict student academic achievement in junior high schools. Sources of data used are books and journals that are relevant to the research theme. The results of the study show that a positive school climate can improve student academic achievement and school climate indicators that can predict junior high school student academic achievement, namely student disruptive behavior which includes aspects of bullying, student discipline includes late students and truant students, and learning activities include student cooperation.
\end{abstract}

Keywords: Academic Achievement, School Climate, School Climate Indicators

\section{Introduction}

Information about the quality of education becomes a benchmark in assessing the performance of the education system in each country. Academic achievement is one of the indicators in assessing the quality of education, therefore studies on academic achievement must be updated and developed. In addition to the changing trends in education globally, the findings of studies on academic achievement can also be used to make decisions and policies to improve the quality of education, especially in Indonesia (1). Academic achievement can be interpreted as the result of student learning achievement in the form of grades or scores after following the learning process which is summarized in the final report of each semester (2). The government's success in providing education is now not only measured by the average score of the National Examination (UN) results but also measured by the results of the PISA survey conducted by the Organization for Economic Co-operation and Development (OECD) (1). PISA is a program for the assessment of international students aged 15 years that surveys the extent to which students' knowledge, skills to participate in social and economic life in the country which are scattered around the world every 3 years (3). PISA measures academic abilities in the areas of reading literacy, mathematical literacy, and scientific literacy, and digs up demographic data related to students' psychology and background. 
The country of Indonesia has participated in the PISA survey since the first PISA survey was conducted in 2000 until now. As a result of the latest PISA survey in 2018, the PISA score of Indonesian students in the language literacy category was ranked 74, mathematics literacy was ranked 73, and scientific literacy was ranked 71 out of 79 participants who took the PISA survey (3). These results indicate that the student's academic achievement has not been able to solve questions on international standard cognitive level. The results of the PISA assessment relate to 4 programs issued by the Ministry of Education and Culture (KEMENDIKBUD) which are called the Independent Learning Program, one of the contents of the policy, namely the National Exam (UN) will be changed to a Minimum Competency Assessment and Character Survey which emphasizes the ability to reason using literacy, numeracy, and character reinforcement (4). This latest policy will be held for the first time in 2021, with the aim of improving the quality of education in Indonesia.

In general, research related to student achievement collects the most recent data relating to data on academic achievement and the factors that influence it. Survey results from PISA show that students' backgrounds continue to influence their chances of benefiting from education and development in many countries (5). For decades, researchers in the social science field have tried to understand how a variety of factors influence student achievement (6). One of the factors that can affect student academic achievement is the school climate. School climate is an interpersonal relationship between teachers, students, and school staff (7). School climate is a broad multidimensional construction that represents the quality and character of school life (8). The term school climate is the same as the school environment, learning environment and school culture (3). The school climate includes the quality and character of school life which is reflected in the norms and values applied in schools, teaching and learning practices in schools, interpersonal relationships between school members, and the organizational structure of the school (9).

The pioneers of research on school climate, namely Halpin and Croft (1963), explain that school climate is a school personality that reveals teachers' collective perceptions of school routines affecting student attitudes and behavior (10). Psychological theory says that the school climate affects student psychology, a positive school climate will form an emotional attachment between students and teachers, this bond affects student academic achievement towards a better direction (11). A positive school climate can be a key factor in efforts to improve student academic achievement (12).

The idea that school climate is important in supporting student academic achievement can be seen from the results of research that are well documented in international literature (13). In general, there is no consensus on the definition of school climate, school climate dimensions, measurement units, and analysis which results in different definitions and units of measurement for each study (14). The lack of research on how school climate indicators affect student achievement in Indonesia, because the majority of research focuses only on identifying problems in principal management and teacher satisfaction (15),(16),(17),(18).

A positive school climate can create a comfortable, safe, and conducive learning atmosphere if the interpersonal relationships between school members are well established. Studies on school climate indicators are well documented in international literature, but in reality in Indonesia, research on this is still very minimal. The focus of researchers is only on principal management and teacher satisfaction, thus causing researchers to find difficulties in identifying school climate indicators in determining student academic achievement. From the background description above, this study aims to find out more about the influence of school climate on student academic achievement and indicators of school climate in influencing student academic achievement. 


\section{Method}

The research design used in this paper is the Literature Review. A literature review is used to collect data or sources related to the research theme. This research resulted in a review of quantitative and qualitative research obtained from books and international journals from Google Scholar, Sagepub Journal, Taylor \& Francis Online. These sources are used to see how school climate affects student achievement from various studies. The keywords used are school climate, learning achievement, the factors that influence the school climate which is positive in increasing student achievement.

The literature review data analysis technique was synthesized using a narrative method by grouping similar extracted data according to the measured results to answer the purpose of writing this article. The data analysis technique from the literature review used by the majority of researchers used descriptive analysis, linear regression test, multiple linear regression test, simple linear regression test, two-stage multiple regression analysis, bootstrap mediation analysis, classical test theory (CTT), hierarchical linear. Model (HLM) and Meta-analysis.

\section{Results and Discussion}

The results of Wibowo et al's research in 2020 show that the school climate has a positive impact on the academic achievement of junior high school students in Indonesia (19). The results of the research by Hultin et al, stated that school climate has a positive correlation with the academic achievement value of junior high school students in Swedia (20). The results of Giez \& Mcintosh's research, revealed that school climate is significantly associated with student academic success in Canada (21). The results of Eugne's 2020 research, said that the school climate variable (perceptions of school safety and student teacher relations) was significantly and positively related to the academically oriented high school program of students in the United States (22). The results of Konold et al's research in 2018, show that a positive school climate makes students in America more involved in school and higher academic achievement by schools (23). The results of research by Aldridge et al in 2013 showed that school climate is closely related to student academic success in Australia and affects student emotional behavior and the success of school reform (24).

The results of a 2016 study by Cornell et al. Revealed that a good school climate can increase the developmental pressure of early adolescents and protect against decreased student motivation and academic achievement in the United States, because a strict school climate and supportive teacher-student relationships can increase engagement. high students, and high learning outcomes, and high aspirations for education (25). The results of research by Davis et al. In 2015 show that school climate is an important factor related to student achievement in New York (6). Ozgenel's research results in 2020, show that a positive school climate has an impact on the performance of administrators, educ

ators and employees in schools which leads to increased student achievement in Turkey (26). The results of research by Sanders et al in 2018, stated that a positive school climate also affects the academic achievement of students with disabilities in the United States (27). Galeta's research results. A in 2017, found that school climate has a significant and positive relationship with student achievement in Ethiopia, but the correlation is weak (28). In general, the findings from this literature study state that there is indeed an influence between the school climate and academic achievement in various countries, because the school climate can make 
the emotional bonds of students and schools tighter so that anything related to school makes students enthusiastic about participating in it. This will affect the student's academic achievement in a better direction. The results of research on school climate from 2013 to 2020 show that school climate does affect student academic achievement, however there are several studies in several countries that say that the contribution of school climate has a weak correlation.

The school climate is divided into two types, namely a positive school climate and a negative school climate. The indicators of positive school climate in measuring student academic achievement vary in each study. Salle 2018 measures student academic achievement into 4 indicators, namely student safety, school environmental conditions, peer and adult relationships, and learning activities (29). Wibowo 2020 measures student academic achievement with indicators of the relationship between students, staff and teachers, safety during the teaching and learning process, and the atmosphere of the school environment (19). Thapa \& Cohen in 2013 measured student academic achievement with 5 indicators, namely student safety, relationships between school members, the learning process, the organizational environment, and the school improvement process (30).

Katsantonis 2020, measures student academic achievement with 4 indicators, namely security, the learning process, the school community and the organizational environment (13). Lewno et al in 2020, measure student academic achievement with 5 indicators, namely security, interpersonal relationships, learning process, organizational environment and school improvement process (8). Sanders in 2018 measures student academic achievement with 3 indicators, namely safety, feelings of security and student emotion and teacher expectations (13).

PISA Results in 2019 measure student academic achievement with 9 indicators into 3 categories, namely first, disruptive behavior in the student environment which includes aspects of bullying, discipline and late behavior and truancy; second, the teaching and learning environment which includes indicators of teacher enthusiasm, teacher support, teaching practices and teacher behavior; third, the school community environment includes indicators of competition, cooperation, a sense of school ownership, and parental involvement (3). Zysberg \& Schwabsky in 2020 measured student academic achievement with 3 indicators, namely interpersonal relationships, violence, and a sense of belonging (31). ).

Cocorada et al 2017, measuring student academic achievement with 7 indicators into 3 categories, namely student and teacher relationships, principal participation, student interaction, school satisfaction, school achievement motivation, relationships between teachers, and safety of citizens at school (32). Negative school climate can be measured using 9 indicators, namely student tardiness, student absence, dropout students, student concern, parental participation, minimal teaching materials, insufficient teacher resources, student readiness to learn, student health conditions (33). Indicators in measuring school climate which are predicted to affect student academic achievement have been suggested by several researchers. There are various indicators in researching school climate, the majority of researchers use school climate indicators rather than negative school climate indicators.

In teaching and learning activities, of course, always expect maximum learning outcomes (2). Analogically, school climate refers to patterns of daily social interactions at school (23). School climate reflects the situation of students, school staff, and parents, experiences about school life socially, emotionally, and socially as a step in increasing academic achievement (30). Studying the impact of school climate on student academic achievement and identifying the factors that shape the school climate can be used as benchmarks in planning and designing appropriate strategies to improve a positive school climate and student academic achievement 
(28). A positive school climate is an effort to improve the quality of learning to achieve superior academic achievement (30). A positive school climate can improve or limit the performance of teachers and other school staff members. A positive school climate can support fostering good relations between school principals and teachers to create a good school climate and improve student academic achievement (28). From several studies on positive school climate, it can be concluded that in general a positive school climate can affect student achievement. In addition, a positive school climate can also influence students' emotions, behavior, reduce the harmful effects of low SES, increase the developmental stresses of early adolescence and increase student contributions to school activities (23) (24) (10) (25) (6) (26). However, some research results reveal that school climate and academic achievement have a significant relationship. However, this correlation is still weak or low because it indirectly affects academic achievement (28) (13).

The impact of a positive school climate is that it can improve student academic achievement, improve student morale and social behavior, minimize bullying in schools, reduce teacher stress and increase teacher job satisfaction in schools (28) (27). Meanwhile, the problematic school climate was detrimental to the academic performance of black students, especially on math outcomes. Students who often arrive late, skip school, drop out of school, student apathy, lack of parental involvement, and lack of materials and resources. teachers, students not ready to learn, and students' poor health (33). A poor school climate increases the risk of student absence and impacts student achievement and risk of dropping out (34). School climate indicators that can predict high school student academic achievement are student safety (bullying, truancy, being late), interpersonal relationships (teachers, principals, students, teachers), participation (feelings of belonging to school, competition, cooperation, parental involvement) (22) (31) (35) (32) (10) (3). The three sub-factors of school climate construction emphasize school academics as an interpersonal orientation in school, an assessment of quality and consistency, and an understanding of norms, values, and behavioral goals (36). In reforming education, the relationship between school climate and academic achievement is important to study because the demands for educational standards at the local and international levels are very high (10).

\section{Conclusion}

Based on a literature review from 2013 to 2020, it can be concluded that the school climate is a picture of life in schools including the relationships between school members. A positive school climate can affect student academic achievement in a better direction. The definition of school climate in Indonesia is more familiarly called the school environment or the atmosphere in the school. Indicators of school climate in affecting academic achievement consist of various kinds. The results of the study show that a positive school climate can improve student academic achievement and school climate indicators that can predict junior high school student academic achievement, namely student disruptive behavior which includes aspects of bullying, student discipline includes late students and truant students, and learning activities include student cooperation.

Acknowledgments. I dedicate my gratitude to previous researchers who have contributed to the results of their research as relevant literature in this literature review, and to the supervisory lecturers, the head of the study program, and friends of the Yogyakarta state university social studies study program who have helped in completing this article. May Allah repay his kindness many times over. Amin 


\section{Reference}

[1] Hewi L, Shaleh M. Refleksi Hasil PISA (The Programme For International Student Assesment): Upaya Perbaikan Bertumpu Pada Pendidikan Anak Usia Dini). J Golden Age. 2020;4(01):30-41.

[2] Syafi'i A, Marfiyanto T, Rodiyah SK. Studi Tentang Prestasi Belajar Siswa Dalam Berbagai Aspek Dan Faktor Yang Mempengaruhi. J Komun Pendidik. 2018;2(2):115.

[3] OECD. PISA 2018 Results WHAT SCHOOL LIFE MEANS FOR STUDENTS' LIVES VOLUME III. Vol. III, OECD Publishing, Paris. 2018.

[4] Web KEMENDIKBUD. Mendikbud Tetapkan Empat Pokok Kebijakan Pendidikan "Merdeka Belajar" [Internet]. Kementrian Pendidikan dan Kebudayaan. 2019. Available from: https://www.kemdikbud.go.id/main/blog/2019/12/mendikbud-tetapkan-empat-pokok-kebijakanpendidikan-merdeka-belajar

[5] OECD. PISA 2015 Results EXCELLENCE AND EQUITY IN EDUCATION VOLUME I. 2016;:I:33-47.

[6] Davis JR, Warner N. Schools Matter: The Positive Relationship Between New York City High Schools' Student Academic Progress and School Climate. Urban Educ. 2018;53(8):959-80.

[7] Tutriyanti DH, Ilmu P, Sosial P, Sarjana PP, Malang UK. Pengaruh iklim sekolah dan kecerdasan emosional terhadap prestasi belajar. 2015;9(2):1118-24.

[8] Lewno-Dumdie BM, Mason BA, Hajovsky DB, Villeneuve EF. Student-Report Measures of School Climate: A Dimensional Review. School Ment Health. 2020;12(1):1-21.

[9] Slade PsCCH do I build a positive environmenteter D\& S. SCHOOL CLIMATE CHANGE How do I build a positive environment for learning? Arias A, editor. USA: ASCD; 2014.

[10] Berkowitz R, Moore H, Astor RA, Benbenishty R. A Research Synthesis of the Associations Between Socioeconomic Background, Inequality, School Climate, and Academic Achievement. Rev Educ Res. 2017;87(2):425-69.

[11] Reynolds KJ, Lee E, Turner I, Bromhead D, Subasic E. How does school climate impact academic achievement? An examination of social identity processes. Sch Psychol Int. 2017;38(1):78-97.

[12] Leavitt RR, Hess RS. School Climate and the Latino-White Achievement Gap School Climate and the Latino-White Achievement Gap. Leadersh Policy Sch. 2017;18(3):1-14.

[13] Katsantonis IG. The Mechanism Underlying the Association of School Climate and Reading Achievement: The Mediating Role of Intrinsic Motivation and Reading Self-Concept in the Greek Context. Tech SocSciJ. 2020;7(59).

[14] Gage NA, Larson A, Chafouleas SM. The Meriden School Climate Survey - Student Version: Preliminary Evidence of Reliability and Validity. Assess Eff Interv. 2015;41(2):67-78.

[15] Damayanti D. Kemampuan Manajerial Kepala Sekolah, Iklim Sekolah Dan Mutu Sekolah Dasar. J Adm Pendidik UPI. 2017;24(1):154-62.

[16] Susanto B. Pengaruh Kepemimpinan Kepala Sekolah, Iklim Sekolah Dan Kompetensi Guru Terhadap Mutu Pendidikan Di Mts Kabupaten Jeneponto. J Manage. 2018;1(2):23-39.

[17] Werang BR, Irianto O. Pengaruh Iklim Sekolah Terhadap Motivasi Dan Kepuasan Kerja Guru Sekolah Dasar Di Distrik Mindiptana, Papua. Musamus J Prim Educ. 2018;1(1):013-23.

[18] Sinay SN, Selatan T. Kepemimpinan Visioner, Iklim Sekolah, Continuing Professional Development Dan Kepuasan Kerja Guru Smp. J Adm Pendidik UPI. 2017;24(1):70-81.

[19] Wibowo YS, Setiawati FA, Qodriah SR, Nizeyumukiza E, Ayriza Y. Do School Climate and Subjective Well-Being Affect Student Achievement in Indonesia?: A Linear Regression Analysis. J Pendidik Progresif. 2020;10(2):183-91.

[20] Hultin H, Eichas K, Ferrer-Wreder L, Dimitrova R, Karlberg M, Galanti MR. Pedagogical and Social School Climate: Psychometric Evaluation and Validation of the Student Edition of PESOC. Scand J Educ Res. 2019;63(4):534-50.

[21] Gietz C, Mcintosh K. Relations Between Student Perceptions of Their School Environment and Academic Achievement. Can J Sch Psychol. 2014;29(3):161-76.

[22] Eugene DR. A Multilevel Model for Examining Perceptions of School Climate, Socioeconomic Status, and Academic Achievement for Secondary School Students. J Educ Students Placed Risk. 2020;25(1):79-99. 
[23] Konold T, Cornell D, Jia Y, Malone M. School Climate, Student Engagement, and Academic Achievement: A Latent Variable, Multilevel Multi-Informant Examination. AERA Open. 2018;4(4):233285841881566.

[24] Aldridge J, Ala'I K. Assessing students' views of school climate: Developing and validating the What's Happening In This School? (WHITS) questionnaire. Improv Sch. 2013;16(1):47-66.

[25] Cornell D, Shukla K, Konold TR. Authoritative School Climate and Student Academic Engagement, Grades, and Aspirations in Middle and High Schools. AERA Open. 2016;2(2):233285841663318.

[26] ÖZGENEL M. An Organizational Factor Predicting School Effectiveness: School Climate. Int J Psychol Educ Stud. 2020;7(1):38-50.

[27] Sanders SM, Durbin JM, Anderson BG, Fogarty LM, Giraldo-Garcia RJ, Voight A. Does a rising school climate lift all boats? Differential associations of perceived climate and achievement for students with disabilities and limited English proficiency. Sch Psychol Int. 2018;39(6):646-62.

[28] Geleta A. Schools Climate and Student Achievement in Secondary Schools of Ethiopia. Eur Sci Journal, ESJ. 2017;13(17):239.

[29] Salle TP La. International perspectives of school climate. Sch Psychol Int. 2018;39(6):1-9.

[30] Thapa A, Cohen J, Guffey S, Higgins-D’Alessandro A. A Review of School Climate Research. Rev Educ Res. 2013;83(3):357-85.

[31] Zysberg L, Schwabsky N. School climate, academic self-efficacy and student achievement. Educ Psychol. 2020;0(0):1-16.

[32] Cocorad E, Cazan A, Orzea IE. Achievement in the Romanian Secondary Education. J Psychoeduc Assess. 2017;36(5):516-22.

[33] Jackson L, Ford J, Randolph C, Schleiden C, Harris-mckoy D, Mcwey L. School Climate as a Link Between High School Black Males 'Math Identity and Outcomes. 2020;

[34] Hamlin D. Can a Positive School Climate Promote Student Attendance? Evidence From New York City. Am Educ Res J. 2020;XX(X):1-28.

[35] Huang T, Hochbein C, Simons J. The relationship among school contexts, principal time use, school climate, and student achievement. Educ Manag Adm Leadersh. 2020;48(2):305-23.

[36] Maxwell S, Reynolds KJ, Lee E, Subasic E, Bromhead D. The Impact of School Climate and School Identification on Academic Achievement: Multilevel Modeling with Student and Teacher Data. 2017;8:1-21 